\title{
KONSEP EKONOMI PADA IBNU KHALDUN DAN AL-GHAZALI
}

\author{
Oleh: \\ Nurul Wahida Aprilya (90100118110) \\ Fakultas Ekonomi dan Bisnis Islam UIN Alauddin Makassar \\ e-mail:wahidaprilya@gmail.com
}

\section{A. Pemikiran Ibnu Khaldun tentang Ekonomi}

Ibnu Khaldun atau nama lengkapnya Abdurrahman Abu Zaid Waliuddin Ibn Khaldun lahir dari Tunisia pada tahun 732H. Ibnu khaldun mempunyai hubungan darah dengan wail bin Hajar, yang merupakan seorang sahabat Nabi yang termuka. Keluarga ibnu khaldun berasal dari Hadramaut, Yaman, dan dikenal sebagai keluarga yang berpengetahuan luas dan berpangkat serta menduduki berbagai jabatan tinggi kenegaraan (Azwar Karim, 2008:391). Selama masa hidup Ibnu Khaldun, ia telah membuat beberapa karya tulis besar yang dinamakan Al-I'bar. Karya ini terdiri dari tiga buah buku yang terbagi jadi tujuh volume, yaitu: Muqaddimah (satu volume) yang memuat pembahasan tentang sosial, yang didalamnya termasuk kegiatan ekonomi. Al-I'bar (empat volume) yang memuat tentang berita-berita mengenai bangsa arab. At-Ta'rif Ibn Khaldun (dua volume) yang memuat pembahasan tentang autobiografi dari ibn khaldun (Jirhanuddin, 2016:94).

Pemikiran Ibnu Khaldun tentang ekonomi (uang dan harga), yaitu:

\section{Teori Uang}

Uang merupakan alat tukar untuk memenuhi kebutuhan manusia. Ibnu Khaldun berpendapat bahwa setiap barang dan jasa mempunyai ukuran nilai ekonomis, ukuran yang digunakan adalah Emas dan Perak, karena kedua logam ini mempunyai ukuran nilai yang tetap. Logam-logam ini juga diterima secara alamiah sebagai uang dimana nilainya ini tidak dipengaruhi oleh flukasi subjektif, karena itulah ibnu Khaldun mendukung penggunaan emas dan perak sebagai standar moneter (Ulum, 2016:26). Ibnu Khaldun juga menjelaskan 
bahwa fungsi emas dan perak, yaitu: Sebagi ukuran nilai, Sebagai alat penyimpan nilai, Sebagai alat tukar di pasar, dan Sebagai akumulasi modal (Ibnu Khaldun, 2004(2):66).

Ibnu Khaldun juga mengemukakan bahwa emas dan perak selain berfungsi sebagai uang juga digunakan sebagai medium pertukaran dan alat pengukur nilai sesuatu. Uang tidak harus mengandung emas dan perak, hanya saja emas dan perak dijadikan standar nilai uang, sementara pemerintah menetapkan harganya secara konsisten. Oleh karena itu Ibnu Khaldun menyarankan agar harga emas dan perak itu konstan meskipun harga-harga lain berfluktuasi tetapi tidak dengan harga emas dan perak (Aryanti, 2018:159).

2. Teori Harga

Ibnu Khaldun dalam kitab muqaddimah-nya menulis satu bab khusus membahas tentang harga, bab tersebut berjudul Harga-harga di Kota. Dalam bab tersebut Ibnu Khaldun mengemukakan bahwa apabila suatu kota berkembang dan populasinya pun bertambah banyak, maka rakyatnya akan makmur, kemudian hal tersebut akan menyebabkan terjadinya kenaikan permintaan (demand) terhadap barang-barang, dan akibatnya harga menjadi naik. Ibnu Khaldun menekankan bahwa faktor yang sangat berpengaruh dalam menetukan harga pasar adalah permintaan dan penawaran. Menurutnya apabila sebuah kota berkembang dengan pesat, dan penduduknya padat, maka persediaan bahan makanan pokok melimpah. Hal ini dapat diartikan bahwa penawaran yang meningkat mengakibatkan harga barang tersebut murah (Hidayatullah, 2017:101)

Ibnu khaldun menekankan bahwa kenaikan penawaran atau penurunan permintaan menyebabkan kenaikan harga, demikian pula sebaliknya apabila kenaikan permintaan atau penurunan penawaran akan menyebabkan penurunan harga. 


\section{B. Pemikiran Al-ghazali tentang Ekonomi}

Al-Ghazali atau nama lengkapnya Abu Hamid Muhammad bin Muhammad bin atTusi Al-Ghazali lahir di Ghazaleh pada tahun 450H. Sejak kecil imam al-Ghazali hidup dalam dunia tasawuf. Beliau tumbuh dan berkembang dalam asuhan seorang sufi, setelah ayangnya meninggal dunia. Al-Ghazali masuk pada fase II. Dimana fase ini banyak dilatarbelakangi olehnya menjamurnya korupsi dan dekadensi moral, serta melebarnya kesenjangan miskin dan kaya, meskipun secara umum kondisi perekonomian masyarakat islam berada pada taraf kemakmuran (Sirajuddin, 2016:59).

Pemikiran ekonomi Al-Ghazali, yaitu: konsep dasar tentang perilaku individu sebagai Economic Agent, konsep tentang harta, konsep kesejahteraan sosial (maslahah), deman dan supply, harga dan keuntungan, nilai dan etika pasar, aktivitas produksi dan hirarkinya, sistem barter dan fungsi uang dalam sebuah perekonomian. Pemikiranpemikiran al-Ghazali dapat ditemukan dalam karya-karyanya, yakni: Ihya' 'Ulum alDin, Mizan al-'Amal dan al-Tibr al-Masbuk fi Nasihat al-Muluk (Fahlefi, 2018:23).

Pembahasan mengenai pemikiran al-Ghazali tentang ekonomi yang terdapat dalam kitab Ihya' Ulum al-Din, yakni:

1. Pertukaran sukarela dan evolusi pasar, yang meliputi: Permintaan, penawaran, harga, dan laba. Etika pelaku dasar.

2. Produksi barang, yang meliputi: Produksi barang-barang kebutuhan dasar sebagai kewajiban sosial, Hierarki produksi, Tahapan produksi, spesialisasi, dan keterkaitannya.

3. Barter dan Evolusi barang, yang meliputi: Problema barter dan kebutuhan terhadap uang, Uang yang tidak bermanfaat dan penimbunan bertentangan dengan hukum illahi. Pemalsuan dan penurunan nilai uang, larangan Riba 
4. Peran negara dan keuangan publik, yang meliputi: Kemajuan ekonomi melalui keadilan, kedamaian, dan stabilitas. Keuangan publik (sumber negara, uatang pulik, dan pengeluaran publik) (Thohir, 2016:93).

Berikut kebijakan ekonomi tentang uang menurut al-Ghazali. yakni:

1. Konsep Uang
a. Uang mengatasi permasalahan barter
b. Uang adalah barang atau benda yang berfungsi sebagai sarana mendapatkan barang lain
c. Uang standar harga barang
d. Uang tidak memiliki nilai instristik dan uang diibaratkan seperti cermin.

2. Larangan menimbun uang

Al-Ghazali melarang penimbunan uang tujuannya agar uang ini beredar dimasyarakat sebagai sarana transaksi dan bukan untuk di monopoli. Penimbunan juga berdampak pada instabilitas perekonomian suatu masyarakat.

3. Praktek perdagangan antar wilayah

Praktik ini dibutuhkan karena kota-kota/wilayah saling mebutuhkan sumber makanan atau bahan pokok lain. Al-Ghazali juga mengatakan bahwa dalam praktek ini disnilah pentingnya alat transportasi untuk melancarkan perdagangan antar wilayah, dan adanya saling timbal balik keuntungan antar wilayah dalam praktek tersebut. 



\section{DAFTAR PUSTAKA}

Aryanti, Y. (2018). Pemikiran Ekonomi Ibn Khaldun; Pendekatan Dinamika Sosial Ekonomi dan Politik. Imara: Jurnal Riset Ekonomi Islam, 2(2), 151-161.

Fahlefi, R. (2018). Pemikiran Ekonomi Al-Ghazali. JURIS (Jurnal Ilmiah Syariah), 11 (1), 22-32.

Hidayatullah, I. (2017). Pemikiran Ibnu Khaldun Tentang Mekanisme Pasar \& Penetapan Harga. Profit: Jurnal Kajian Ekonomi dan Perbankan Syariah, 1(1), 92-129.

Ibn Khaldun, Abdul Rahman Ibn Mohammad Ibn Khaldun, (2004) Mukaqqadimah, ter. Masturi Irham dkk, Juz II, Damaskus, Maktabah Al-Hidayah, Al-Tab’ah Ula.

Jirhanuddin, J. (2016). Konsep Pengelolaan Pajak yang Adil Perspektif Ibnu Khaldun. Jurnal Al-Qardh. 1(2), 90-103.

Karim, Adiwarman Azwar. (2008). Sejarah Pemikiran Ekonomi Islam, Jakarta: PT. Radja Grafindo Persada.

Sirajuddin, S. (2016). Konsep Pemikiran Ekonomi Al-Ghazali. LaaMaisyir: Jurnal Ekonomi Islam, 3(1).

Thohir, M. M. B. (2016). Pemikiran Imam Al-Ghazali Tentang Ekonomi Islam dalam Kitab Ihya'Ulumuddin. IQTISHODUNA: Jurnal Ekonomi Islam, 5(2), 76-93.

Ulum,B. (2016). Kontribusi Ibnu Khaldun Terhadap Perkembangan Ekonomi Islam. Iqtishoda: Jurnal Ekonomi Syariah, 1(2), 17-32. 